ELORE (ISSN 1456-3010), vol. $16-2 / 2009$.

Julkaisija: Suomen Kansantietouden Tutkijain Seura ry.

[http://www.elore.fi/arkisto/2_09/kirjallisuus_niiranen_2_09.pdf]

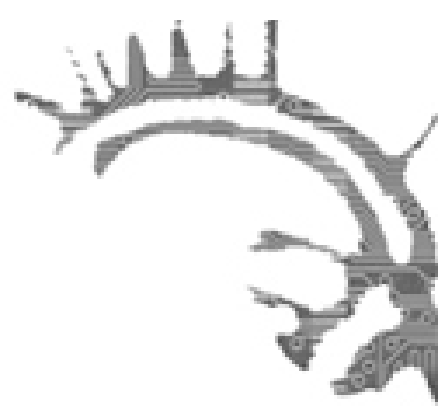

\title{
KiRJA-ARVIO:
}

\section{MONIPUOLINEN TUTKIMUS RUNOLAULUSTA}

Huttu-Hiltunen, Pekeka 2008: Länsivienalainen runolaulu 1900-luvulla. Kunden runolaulajan laulutyylin kulttuurisensitiivinen musiikkianalyysi. Helsinki: Sibelius-Akatemia; Kubmo: Juminkeko.

\section{Elina Niiranen}

Kansanmusiikintutkija Pekka Huttu-Hiltusen väitöskirja Länsivienalainen runolaulu 1900-luvulla. Kunden runolaulajan laulutyylin kulttuurisensitiivinen musiikkeianalyysi perustuu kirjoittajan kenttätöihin Vienan Karjalassa vuosina 1996-2007 sekä laajaan arkisto- ja lähdeaineistomateriaaliin. Tutkimus on musiikkianalyyttinen kuvaus kuuden läntisestä Vienasta kotoisin olevan laulajan runolaulurepertoaareista: tutkittavista vanhin on syntynyt 1866 ja nuorin 1924. Laulajat on valittu kolmella perusteella: heidän elinkaarensa osuvat 1900-luvun eri vaiheisiin, he ovat oppineet laulutapansa LänsiVienassa ja heidät on aikanaan tiedetty hyviksi laulajiksi. Tutkimus jakautuu kahteen osaan, joista ensimmäisessä kuvataan niitä kulttuurisia ja yhteiskunnallisia olosuhteita, joissa runolaulu on Vienan Karjalassa elänyt. Tähän osioon kuuluu myös tutkijan Vienan Karjalassa 1990-luvun loppupuolella ja 2000-luvun alussa tekemän kenttätyön esittely. Työn toinen laaja osio on musiikkianalyyttinen. Tähänkin osuuteen sisältyy toki esimerkiksi laulajien elämänvaiheiden kuvausta, arkistomateriaalin esittelyä ja runolauluun liittyvää kulttuurista tietoa. Pääosin kuitenkin keskitytään kunkin laulajan runolauluohjelmiston kuvaamiseen ja analysoimiseen.

Tutkimus on kokonaisuudessaan varsin laaja. Kirjoittaja on paneutunut Vienan Karjalan historiaan ja kulttuuriin lukemalla suuren määrän taustakirjallisuutta, minkä lisäksi väitöskirja pohjautuu lukuisiin kirjoittajan itse tekemiin haastatteluihin. Mu- 


\section{ELINA Nitranen}

siikkia käsittelevä osuus pohjautuu mittavaan analyysityöhön suuren sävelmäaineiston pohjalta. Musiikkianalyyttinen osuus onkin selvästi tutkimuksen kompaktimpi osuus. Kulttuuriin ja historiaan keskittyvää alkuosaa vaivaa hajanaisuus, liian moneen suuntaan harovat intressit ja kulttuurista tehtyjen tulkintojen vähäiset perustelut. Yleistä asutus- ja muuta historiallista taustoitusta Vienan osalta olisikin voinut karsia ja rajata nimenomaan tutkittuun ajanjaksoon. Nyt kulttuurinen osuus, joka perustuu taustakirjallisuuteen, ei taustoita tutkimuksen musiikkianalyyttistä osaa. Tästä syystä kulttuuria käsittelevä osuus ja musiikkiosuus pysyvät kovin erillisinä toisistaan eikä niiden välille synny tutkimuksessa vuoropuhelua.

\section{ONGELMALLINEN KULTTUURINEN RAJAUS}

Huttu-Hiltunen on ratkaissut tutkimuksessaan tapahtumarikkaan ajanjakson ja kulttuurisesti hajanaisen alueen tutkimisen ongelmat tarkastelemalla 1900-lukua tiettyjen paikalliskulttuurin elementtien ja yhteiskunnallisten murrosaikojen yleisluontoisella kuvauksella. Paikalliskulttuurin kuvaus on tarkempaa, kun hän tarkastelee 1900-luvun alkuvuosikymmeniä. Mitä lähemmäs 1900-luvun loppua tullaan, sitä aukkoisemmaksi kuvaaminen muuttuu. Tämä on ymmärrettävää: 1900-luvun loppua kuvaavassa osiossa kirjoittaja käyttää pelkästään haastatteluja selostuksensa pohjana. Syy tähän on ilmeinen: mitä lähemmäs nykyhetkeä tullaan, sitä vähemmän on olemassa muiden tekemiä tutkimuksia. Lähdeaineistojen puutetta olisi paikannut esimerkiksi tilastotietojen käyttö ja omien kenttäkokemusten perusteellinen hyödyntäminen. Juuri lähdeaineistojen puutteen vuoksi 1900-luvun lopun Länsi-Vienasta syntyykin tutkimuksessa osin harhaanjohtava käsitys. Kylien monietnisyyttä ei esitellä ja asuttuina kylinä Huttu-Hiltunen mainitsee vain murto-osan kyseisellä maantieteellisellä alueella olevista asutuista kylistä: esimerkiksi Uusi-Jyskyjärvi, Kepa, Kuusiniemi ja Borovoi jäävät kokonaan mainitsematta. 1900-luvun Vienasta kirjoitettaessa olisi mielestäni ollut erittäin huomionarvoista mainita puuteollisuuden kasvuun tarvittu työväestö, joka muutti muualta Neuvostoliitosta, Amerikasta ja Suomesta. Myös tämän työvoiman tarpeisiin synnytetyt parakkikylät ja sosialismin myötä tullut uudenlainen elinkeinojen organisoituminen muuttivat Länsi-Vienan kulttuurista todellisuutta huomattavasti. Myös kulttuurin poliittinen ohjailu, joka vaikutti tekstisisällöiltään uudenlaisen runolaulun, novinan, syntyyn, olisi mielestäni kuulunut runolaulun taustalla olevien kulttuuristen muutosten esittelyyn.

Keskeinen käsite Länsi-Viena, nimenomaan tämän tutkimuksen kannalta rajattuna tutkimusalueena ja kulttuuripiirinä, olisi kaivannut lisää perusteluja. Toisessa luvussa kirjoittaja määrittelee Länsi-Vienan kulttuuripiiriksi, jolle hän antaa maantieteelliset rajat. Tähän kuuluvat Suomen puolella sijaitsevat kylät Kuivajärvi, Hietajärvi, Rimmi ja Venäjän puolella nykyiset Kalevalan ja Kostamuksen piirit. Länsi-Viena kirjoittajan määrittelemänä maantieteellisenä alueena on laajempi kuin tutkimuksessa myöhemmin esitelty ja useassa kohtaa siteerattu historioitsija Matti Pöllän asutushistoriallisiin tutkimuksiin perustuva Länsi-Viena. Nämä kaksi alueiltaan poikkeavaa kulttuuripiiriä hämmentävät lukijaa, sillä kirjoittaja ei huomaa mainita kumpaa kulttuurista aluetta 
hän kulloinkin tarkoittaa. Kirjoittajan Länsi-Viena poikkeaa myös jonkin verran siitä alueesta, jonka Pertti Virtaranta esittelee läntisten vienalaismurteiden alueeksi. Tutkittavien laulajien asuinpaikat sijoittuvat maantieteellisesti paljon suppeammalle alueelle, kuin se Länsi-Viena, jonka kirjoittaja märittelee. Mihin kirjoittajan kulttuurinen rajaus perustuu?

Tutkimukseen valittu pitkä historiallinen ajanjakso tekee kulttuuripiirin rajaamisen maantieteellisesti hankalaksi: Venäjän Karjalan puolella sijaitseva Länsi-Vienan alue oli kulttuurisesti ja etnisesti 1900-luvun lopussa aivan erilainen kuin 1900-luvun alussa. Näistä muutoksista Huttu-Hiltunen mainitsee luvun 5 alussa, mutta hän ei ota näitä muutoksia esiin kirjoittaessaan Vienasta 1900-luvulla. Mitä lähemmäs 1900-luvun loppua tullaan, Huttu-Hiltusen määrittelemää Länsi-Vienaa kuvattaessa ei voida puhua enää pelkästään karjalaisesta kulttuuripiiristä. Kulttuuripiirejä eivät määritä 1900-luvun lopun Vienan Karjalassa maantieteelliset rajat, vaan yhä useammin ne ovat globaaleja. Vuosituhannen vaihteen karjalaisuus sisälsi myös elementtejä, joita 1900-luvun alun karjalaisuuteen tai vienalaisuuteen ei kuulunut: sekä venäjän- että karjalankielisen arkipäivän, kulttuurin, jossa sulautuivat monista suunnista tulevat vaikutteet ja jatkuvan neuvottelun eri etnisten ryhmien kesken. Venäjän kielellä laulaminen on toisen maailmansodan jälkeen vahvistanut asemaansa Vienan Karjalassa myös karjalaisten keskuudessa ja on keskeinen osa ihmisten arkea ja juhlaa.

\section{RunOlaulun OIVALTAVAA KUVAAMista}

Tutkimuksen musiikkianalyyttisessä osuudessa kirjoittaja käy perusteellisesti läpi kuuden laulajan runolaulurepertuaarit. Määrällisesti painottuu Anni Tenisovan laulurepertuaari, joka käsittää 1440 säettä, kun suppein analysoitu laulurepertuaari on Anni Lehtosen 77 säkeen runolauluohjelmisto. Huttu-Hiltunen käyttää musiikkianalyysissään apuna Albert Lordin (1960) ja Milman Parryn kehittämää formula-käsitettä, jota aiemminkin ovat käyttäneet muistinvaraisen musiikkianalyysin työkaluna Suomessa ainakin Jukka Louhivuori ja Hannu Saha. Esimerkit näistä musiikkianalyyttisistä tutkimuksista olisivat syventäneet lukijalle tämän käsitteen mahdollisuuksia nimenomaan musiikin tutkimuksessa. Formula-käsitteen avulla Huttu-Hiltunen kuvaa runolaulua osuvasti. Hän mainitsee laulamisen perustuvan runon ja sävelmän tasolla runosäkeiden ja sävelmäaiheiden kantamuotojen monipuoliseen käyttöön. Näitä kantamuotoja kirjoittaja on jäljittänyt musiikkiaineistosta säkeiden melodista hahmoa analysoimalla. Juuri kantamuotojen taitaminen ja niiden luova tuottaminen nousevat keskeisiksi Huttu-Hiltusen tarkastellessa eri laulajia. Kirjoittaja erittelee kunkin laulajan kohdalla heidän käyttämänsä musiikillisten säkeiden kantamuodot niin esi- kuin jälkisäkeissä. Laulajien joukosta erottuu hyvinkin luovia laulajia, jotka hallitsevat useita sävelmäsäkeiden kantamuotoja ja käyttävät niitä monipuolisesti. Toiset laulajista taas ovat laulamisessaan toistavampia, vähemmän muuntelevia. Käsitys runolaulusta uutta tuottavana, persoonallisena lauluilmaisuna syvenee tutkimuksen tuloksia kokoavassa osuudessa. Runolaulusävelmien osalta Huttu-Hiltunen tulee siihen jo tunnettuun tulokseen, että runolaulumelodiat voidaan jakaa häsävelmiin ja yleistyypin sävelmiin. Sen sijaan 


\section{Elina Nitranen}

tekstien osalta kytkentä tiettyyn sävelmätyyppiin ei kyseisen aineistonkaan kohdalla näytä olevan kovin vakiintunut, sillä esimerkiksi häärunoja on voitu laulaa yleistyypin sävelmällä. Huttu-Hiltusen havainnot sävelmän ja tekstin välisistä yhteyksistä etenkin Domna Huovisen lauluston kohdalla ovat varsin mielenkiintoisia. Tutkimuksen parasta antia onkin runolaulun oivaltava kuvaaminen, joka pohjaa perusteelliseen analyysityöhön ja monipuolisten musiikkianalyyttisten menetelmien käyttöön.

Vaikka tutkimuksen alkuosaa vaivaa paikoitellen epätarkkuus johtuen liian laajoista tutkimuskysymyksistä ja rajauksen ongelmista, kokonaisuudessaan tutkimus tuo tärkeää uutta tietoa Länsi-Vienan alueella asuneiden laulajien runolaulurepertuaareista, muuntelusta ja tavoista rakentaa musiikillista kokonaisuutta laulamisen kuluessa tukeutuen tiettyihin kantamuotoihin. Tutkimus ilmestyy hyvään aikaan, sillä innostus runolauluun on lisääntynyt uuden kansanmusiikin tulemisen myötä jatkuvasti. Suomessa on aiemmin ilmestynyt vain yksi runolaulua musiikillisena ilmiönä tarkasteleva tieteellinen väitöskirja, jossa vertailtiin virolaisia ja suomalaisia runomelodioita (Launis 1910). Sen sijaan viime vuosina on ilmestynyt useita kalevalamittaisia runotekstejä ja niiden kautta yhteisöä ja merkityksiä analysoivia väitöstutkimuksia (esim. Timonen 2004; Tarkka 2005) ja jo aiemmin yksi nimenomaan vienalaiseen runolauluun keskittyvä ainesjulkaisu (Virtaranta 1973). Vienan Karjalasta on tallennettu suuri määrä runolaulua ja HuttuHiltusen tutkimus vastaa nyt siihen tiedonjanoon, jota tämän alueen lauluperinnettä kohtaan on jo valmiiksi olemassa. Tutkimuksen merkitys Venäjän Karjalassa asuvalle karjalaiselle väestölle on tärkeä, koska se tekee näkyväksi ainutlaatuisen laulukulttuurin olemassaolon ja osoittaa sen jatkuvuuden. Huttu-Hiltusen väitöskirja on myös hyvä osoitus siitä, että yhteistyö tutkijoiden kanssa johtaa konkreettiseen lopputulokseen.

\section{KirjallisuUs}

LAUNIS, ARMAS 1910: Über Art, Entstebung und Verbreitung der Estnish-Finnisschen Runenemelodien. Helsinki: SKS.

LORD, ALBERT B. 1960: The Singer of Tales. Cambridge. Harvard University Press.

TARKKA, LOT'TE 2005: Rajarahvaan laulu. Tutkimus Vuokkiniemen kalevalamittaisesta runokulttuurista. Helsinki: SKS.

TIMONEN, SENNI 2004: Minä, tila ja tunne. Näkökulmia kalevalamittaiseen kansanlyriikekaan. Helsinki: SKS.

VIRTARANTA, PERTTI 1973: Vienalaisia lastenlauluja. Castrenianumin toimitteita 3. Helsinki: Helsingin yliopisto.

Filosofian maisteri Elina Niiranen on Tampereen yliopiston musiikintutkimuksen laitoksen etnomusikologian jatko-opiskelija, joka valmistelee väitöskirjaa Venäjän pohjoisen Karjalan uudemmasta lauluperinteestä. 